\title{
DECENTRALIZACJA CZY RECENTRALIZACJA? KILKA UWAG O REGULACJ KONSTYTUCYJNEJ I PRAKTYCE FUNKCJONOWANIA SAMORZA¿DU TERYTORIALNEGO W POLSCE
}

Pojęcia decentralizacji i samorządności są ze sobą nierozerwalnie połączone. Cechą niezbywalną pojęcia samorządności jest to, iż może ona istnieć jedynie w państwie zdecentralizowanym, w którym przyznaje się obywatelom prawo do własnych decyzji, podejmowanych zgodnie z ich interesami. Samorząd jest zaś emanacją interesów tych obywateli - korporacją prawa publicznego, czyli podmiotem administracji publicznej wyposażonym we władztwo administracyjne. Jego nieodzownym elementem jest obligatoryjne członkostwo „z mocy samego prawa”, czytelne zasady przynależności (zamieszkiwanie na terenie jednostki samorządu) i istnienie niezależnie od liczby lub zmiany członków. Jest to najpełniej rozumiana „mikrodemokracja”, której państwo przekazuje część swojej funkcji administracyjnej i wyposaża w osobowość prawną - zadania administracji publicznej wykonują zainteresowani obywatele lub ich grupy, wyposażeni w określone kompetencje i władztwo administracyjne. Łączy się z tym obowiązek wykonywania przekazanych funkcji i wyłączność realizacji tego obowiązku, dodatkowo zapewniona gwarancjami prawnymi, iż poza

Jowanka Jakubek-Lalik - doktor nauk prawnych, Instytut Nauk Prawno-Administracyjnych, Uniwersytet Warszawski. 
wyznaczonym zakresem nadzoru państwo nie może mieszać się do jego działalności. Przez samorząd najpełniej realizują się zasady subsydiarności i decentralizacji.

Samorząd ma więc istotną i niezbywalną cechę - daje prawo do załatwiania swoich spraw zgodnie $\mathrm{z}$ własnymi interesami i ich identyfikacją. W tym uprawnieniu zawiera się założenie, że dana społeczność może postępować w niektórych sprawach inaczej niż inne wspólnoty komunalne. Decentralizacja zapewnia uznanie prawa mniejszości do własnych decyzji i wyborów, nawet jeżeli nie będą one zawsze do końca trafne. Działania w ramach zadań własnych społeczności lokalnych nie powinny i - na mocy obowiązującego prawa - nie mogą być oceniane pod kątem celowości czy rzetelności, ponieważ to ingeruje w samodzielność samorządu i zawsze oznacza stosowanie kryteriów ocennych wobec działań prowadzonych na własny rachunek. Kryterium legalności pozostaje więc jedynym kryterium nadzoru nad działaniami samorządu terytorialnego w ramach zadań własnych ${ }^{1}$. Współcześnie decentralizacja nie polega bowiem jedynie na samodzielności w sferze imperium (władczej), ale stanowi podstawę samodzielnego zarządzania sprawami publicznymi przede wszystkim w rozumieniu gospodarczym, w systemie sieciowym, a nie hierarchicznym, przez osiąganie korzyści społecznych i gospodarczych w skali lokalnej czy regionalnej. Samorządność realizuje się poprzez działanie na rzecz rozwoju danej jednostki samorządu terytorialnego, organizowanie dostarczania usług publicznych, a także współdziałanie i konkurowanie $\mathrm{z}$ innymi samorządami oraz udział w rynkach ponadlokalnych i ponadregionalnych ${ }^{2}$.

${ }^{1}$ Samodzielność decyzyjna samorządu nie zawsze jest kwestią bezwarunkową czy niekontrowersyjną. Problemy mogą pojawić się np. w standaryzowanych usługach publicznych, jak np. edukacja czy ochrona zdrowia. Decentralizacja władzy publicznej nie może stać w sprzeczności z gwarantowaną konstytucyjnie równością obywateli w dostępie do usług publicznych.

${ }^{2}$ M. Kulesza, Ile decentralizacji $w$ centralizacji, czyli o nawykach uczonych administratywistów, ST 2009/12. 


\section{Przywrócenie i reformowanie samorządu terytorialnego}

Przywrócenie w 1990 r. samorządu terytorialnego (i pogłębienie decentralizacji w 1998 r.) zmieniło radykalnie ustrój państwa, stawiając na rozwiązania zgodne z zasadą pomocniczości. Pomiędzy założeniami funkcjonowania władzy lokalnej w PRL i III RP była ewidentna dychotomia, która dotyczyła nie tylko kwestii organizacji i funkcjonowania państwa, ale przede wszystkim dystrybucji władzy publicznej na poziomie centralnym i lokalnym. Po ustroju socjalistycznym odziedziczono skomplikowanie, wielopoziomowość, przecinanie się różnych podziałów administracji specjalnych oraz silnie scentralizowane struktury administracji, oparte na powiązaniach resortowych, zarówno w aspekcie decyzyjnym, jak i finansowym. Po zmianach politycznych i odejściu w przeszłość kierowniczej roli partii, odpadła przesłanka centralizmu w rządzeniu, a stała się ona przeszkodą w budowie administracji demokratycznego państwa.

Odbudowa samorządu była jednym z koniecznych warunków przywrócenia w Polsce ustroju demokratycznego i budowy społeczeństwa obywatelskiego. Bez prawdziwego samorządu - czyli przekazania na poziom lokalnych wspólnot realnych kompetencji władzy publicznej - i bez społecznego zaangażowania niemożliwy byłby rozwój kraju, będący wynikiem pracy obywateli. W PRL odcięcie wspólnot lokalnych od decydowania blokowało inicjatywy i działalność ludzi, dopiero stworzenie właściwych warunków do swobodnego działania mieszkańców gmin i powiatów dało możliwość działania władzom lokalnym, które odgrywają znaczną rolę w rozwoju gospodarczym ${ }^{3}$.

Dla polskiej administracji najważniejsze, wręcz rewolucyjne, znaczenie miał niewątpliwie rok 1990, w którym odrodził się samorząd terytorialny po 40-letnim nieistnieniu. Nadrzędnym celem tej reformy było przekazanie zadań w ręce samorządu i odcięcie bieżącego zarządzania sprawami lokalnymi od centrum. Zerwano z za-

\footnotetext{
${ }^{3}$ J. Regulski, Samorząd a model państwa, „Infos” z 20.05.2010 r., s. 2.
} 
sadą jednolitego funduszu własności państwowej i jednolitej władzy państwowej, a także stworzono znacznie lepsze warunki dla rozwoju społeczności lokalnych, co ułatwiło procesy ich upodmiotowienia. Wzmocniono konkurencję między ośrodkami regionalnymi, a także zapewniono instrumenty dla lepszego zarządzania usługami publicznymi.

Po reformie przywracającej samorząd terytorialny oczekiwano znaczącego wzmocnienia zdolności państwa do sprawnego funkcjonowania. Była ona konieczną zmianą ustrojową, gdyż bez tego kroku groziło utrzymanie systemu zaprogramowanego na centralizm państwowy i brak demokratycznej kontroli nad procesami decyzyjnymi w administracji. W 1998 r. podjęto następny etap reformy decentralizacyjnej, przekazujący do samorządu kolejną dużą dozę współodpowiedzialności za rządzenie państwem oraz kompetencje dotąd zarezerwowane dla administracji rządowej. Kontynuacja reform samorządowych była ponadto ściśle zbieżna ze staraniami Polski o przystąpienie do Unii Europejskiej, przygotowując na nowe wyzwania w zakresie wielopoziomowego zarządzania publicznego, absorpcji funduszy europejskich, uczestnictwa w programach europejskich, a nawet do decydowania w sprawach europejskich, stawiając ścisłą cezurę pomiędzy zadaniami państwowymi i samorządowymi.

Głównym założeniem reformy była niewątpliwie decentralizacja władzy państwowej, a także kontynuacja zmian zapoczątkowanych w 1989 i 1990 r. Aby to osiągnąć, należało na nowo ułożyć kompetencje między centrum a terenem, wyposażyć jednostki samorządu terytorialnego w samodzielność oraz zdefiniować odpowiedzialność za sprawy publiczne na poziomie lokalnym. Kolejnym celem było uporządkowanie terytorialnej organizacji państwa w postaci bardziej przejrzystego i zrozumiałego podziału oraz racjonalizacja struktur administracyjnych. Po wprowadzeniu dwóch kolejnych szczebli samorządu terytorialnego pojawiła się kolejna płaszczyzna dla tworzenia elit lokalnych, co miało prowadzić do dalszej demokratyzacji kraju i walki ze spuścizną po PRL. Mechanizmy demokracji lokalnej uzyskały silny instrument prawny w postaci kontroli obywatelskiej władz samorządowych. Ważną konsekwencją reformy była także za- 
kładana przebudowa systemu finansów publicznych i impuls do bardziej efektywnego zarządzania finansami na wszystkich szczeblach administracji.

Podstawy nowego ustroju administracyjnego okazały się trwałe i przez kolejne lata były umacniane, pomimo nieuniknionych korekt w podziale administracyjnym. Reforma miała bowiem służyć przebudowie świadomości administracyjnej, nowemu podziałowi kompetencji między rząd i samorząd, który dopiero w postaci nowych szczebli mógł je w sposób efektywny wykonywać. Zmiany te niewątpliwie unowocześniły i usprawniły państwo, pozwalając na sprawniejsze rządzenie i sprostanie nowym wyzwaniom. Jednocześnie wzmocniły procesy demokratycznej kontroli nad władzą, współodpowiedzialność obywateli za państwo, dały mocniejsze poczucie partycypacji w sprawach publicznych.

Reformatorom udało się osiągnąć większość założonych celów. I choć naturalną cechą wszelkich struktur administracyjnych jest konserwatyzm, niechęć do zmian i bezwład, czyli opór wobec wszelkich działań reformatorskich, szczególnie tak głębokich, jak te o charakterze ustrojowym, determinacja przy wprowadzaniu reformy uczyniła $\mathrm{z}$ niej proces nieodwracalny, który doprowadził także do przebudowy ustroju politycznego Polski ${ }^{4}$. Między innymi dzięki tej reformie polski samorząd można uznać za jeden z bardziej nowoczesnych, szczególnie w tej części Europy.

\section{Konstytucyjne ramy samorządu terytorialnego}

Prace nad Konstytucją RP trwały od początku lat 90. ubiegłego wieku i miały miejsce z pełną świadomością fundamentalnego znaczenia zasady pomocniczości, decentralizacji i samodzielności samorządu terytorialnego. Już tzw. Mała Konstytucja ${ }^{5}$ z 1992 r. określała samo-

\footnotetext{
${ }^{4}$ H. Izdebski, M. Kulesza, Administracja publiczna. Zagadnienia ogólne, Warszawa 2004, s. 344.

${ }^{5}$ Ustawa konstytucyjna z 17.10.1992 r. o wzajemnych stosunkach między władzą ustawodawczą i wykonawczą Rzeczypospolitej Polskiej oraz o samorządzie terytorialnym (Dz.U. z 1997 r. poz. 483).
} 
rząd jako „podstawową formę organizacji lokalnego życia publicznego" (art. 70 ust. 1) i przyznawała jednostkom samorządu terytorialnego podmiotowość prawną i kompetencje w sprawach publicznych ${ }^{6}$. Wcześniej zaś zmieniono tytuł rozdziału 6 Konstytucji z 22.07.1952 r. z „Terenowe organy władzy i administracji państwowej” na „Samorząd terytorialny”, z pierwszym przepisem tego rozdziału sytuującym samorząd terytorialny jako podstawową formę organizacji życia publicznego w gminie ${ }^{7}$.

Konstytucja RP poświęca samorządowi terytorialnemu cały rozdział VII (art. 163-172) oraz fundamentalne dla podstaw prawnych funkcjonowania samorządu art. 15 i 16, głoszące zasadę decentralizacji władzy publicznej, uwzględnienie więzi społecznych, gospodarczych lub kulturowych przy podziale terytorialnym, tworzenie ex lege wspólnoty samorządowej przez ogół mieszkańców jednostek zasadniczego podziału terytorialnego. Istotne jest także postanowienie, że samorząd terytorialny uczestniczy w sprawowaniu władzy publicznej, a zadania publiczne wykonuje w imieniu własnym i na własną odpowiedzialność. Do fundamentów ustrojowych, na których został oparty system po 1989 r., Konstytucja RP zalicza przede wszystkim:

- zasadę demokratycznego państwa prawnego,

- zasadę pluralizmu politycznego,

- zasadę decentralizacji,

- zasadę pomocniczości,

- zasadę samodzielności gminy,

- domniemanie kompetencji na rzecz gminy,

- zasadę legalizmu.

W rozdziale VII Konstytucja RP doprecyzowuje podstawowy charakter gminy (art. 164 ust. 1) i domniemanie na jej rzecz kompetencji (art. 164 ust. 3), co najmniej dwuszczeblową konstrukcję samorządu (art. 164 ust. 2). Jako obligatoryjne przyjmuje istnienie samorządu

${ }^{6}$ H. Izdebski, Samorząd terytorialny. Podstawy ustroju i działalności, Warszawa 2009, s. 80 i n.

7 Od grudnia 1989 r. Konstytucja nosiła zmieniony tytuł Konstytucji Rzeczypospolitej Polskiej. 
regionalnego, a także bezpośrednie wybory do wszystkich organów stanowiących samorządu. Ważne znaczenie ma także postanowienie art. 163, zawierające domniemanie kompetencji w zakresie wykonywania zadań publicznych na rzecz samorządu. Artykuł 165 chroni prawa majątkowe i podmiotowość prawną jednostek samorządu, zaś art. 166 akcentuje rolę samorządu w zaspokajaniu potrzeb wspólnoty samorządowej. Dodatkową gwarancją podmiotowości wspólnoty mieszkańców jest przyznanie im w art. 170 prawa do decydowania w drodze referendum, zaś w art. 171 dokonano ograniczenia i doprecyzowania granic nadzoru nad samorządem terytorialnym.

Suma postanowień Konstytucji RP (i wcześniejszej ustawy o samorządzie terytorialnym) oznacza radykalne zerwanie $\mathrm{z}$ tradycją rad narodowych i otwiera drzwi do późniejszej dalszej decentralizacji. Podkreślenie odrębnej podmiotowości publicznoprawnej, wykonywanie zadań publicznych „w imieniu własnym i na własną odpowiedzialność" (art. 16 ust. 2) i ograniczenie dualizmu administracyjnego do szczebla wojewódzkiego podkreśla rolę samorządności w sprawowaniu władzy publicznej. Dodatkową istotną cechą jest także brak hierarchicznego podporządkowania jednostek samorządu terytorialnego, z których każda stanowi w pełni samodzielną społeczność lokalną, o demokratycznej strukturze organizacji wewnętrznej, jest wyodrębniona przez ustawę strukturalnie i podmiotowo w celu zdecentralizowanego wykonywania zasadniczej części lokalnych zadań z zakresu administracji publicznej, z prawem do korzystania z prawnych form działania administracji publicznej.

Tak szeroko zakreślone pole dla funkcjonowania samorządu nie pozostaje jednak bez problemów interpretacyjnych. Współcześnie największe kontrowersje budzi wyprowadzana $\mathrm{z}$ art. 7 zasada legalizmu, przewidująca działanie władzy publicznej na podstawie i w granicach prawa, czyli możność podejmowania tylko takich rozstrzygnięć i działań władczych, które są przez prawo wyraźnie dozwolone lub nakazane. Zawężająca interpretacja w orzeczeniach sądowych i Trybunału Konstytucyjnego powoduje jednak, że klauzulę tę rozciąga się na działania niewładcze samorządu terytorialnego (np. działania 
społeczne). Tymczasem, na co zwracał uwagę wielokrotnie M. Kulesza, współczesna działalność samorządu terytorialnego bardzo daleko wykracza poza klasyczną sferę porządkowo-reglamentacyjną (imperium), koncentrując się szeroko na zaspokajaniu zbiorowych potrzeb społecznych i zarządzaniu rozwojem. Te sfery zaś polegają głównie na stosowaniu działań niewładczych i wykorzystaniu majątku publicznego (dominium). W tych sytuacjach podstawa prawna działania administracji jest znacznie swobodniejsza niż klasycznie stosowana zasada działania tylko "na podstawie i w granicach prawa”. Tymczasem cała linia orzecznicza sądów administracyjnych przyjmuje założenie, że zadaniem publicznym jest jedynie to, co zostało pozytywnie i konkretnie określone w przepisach szczegółowych, zaś działania gminy bez takiego postanowienia pozbawione są podstawy prawnej - niejako w oderwaniu od przepisów art. 163 w zw. z art. 164 ust. 3 oraz art. 165 ust. 2 Konstytucji $\mathrm{RP}^{8}$. Okazuje się więc, że wyzwolenie gmin spod mechanizmów odgórnego decydowania i przyjęcie wąskiego nadzoru opartego na kryterium legalności szybko zaczęło zmierzać w kierunku kontroli celowości, co czyni samodzielność gminy de facto fikcyjną .

\section{Praktyka funkcjonowania samorządu}

Jednym z podstawowych problemów w funkcjonowaniu samorządu terytorialnego było od początku błędne rozumienie jego istoty, które w Polsce często koncentrowało się na określaniu tym mianem władz lokalnych - wójta/burmistrza/prezydenta miasta czy też rady. Istota samorządu jest jednak zupełnie inna: to prawo i zdolność do zarządzania swoimi sprawami przynależne społeczności lokalnej. Władze lokalne to instytucje, które jednak - jak pokazuje historia - nie muszą mieć charakteru samorządowego. Definicja samorządu terytorialnego w Europejskiej Karcie Samorządu Lokalnego wskazuje, że jest to „prawo i zdolność społeczności lokalnych, w granicach określonych prawem, do kierowania i zarządzania zasadniczą częś-

\footnotetext{
${ }^{8}$ M. Kulesza, Ile decentralizacji..., s. 7-10.

9 M. Kulesza, Ile decentralizacji..., s. 15.
} 
cią spraw publicznych na ich własną odpowiedzialność i w interesie ich mieszkańców"10. To określenie istoty samorządu kładzie nacisk na aspekt podmiotowy - jej osią nie jest jednostka samorządu terytorialnego, ale społeczność lokalna. Nie ma tutaj mowy o elementach organizacyjnych jednostek samorządu terytorialnego, a podstawę samorządności ujmuje się w charakterze prawa podmiotowego społeczności lokalnych do sprawowania władztwa publicznego. Dopiero w dalszej kolejności Karta głosi, iż „prawo to jest realizowane przez rady lub zgromadzenia, w których skład wchodzą członkowie wybierani w wyborach wolnych, tajnych, równych, bezpośrednich i powszechnych i które mogą dysponować organami wykonawczymi im podlegającymi [...]"11.

Samorządność może się rozwijać tylko w państwie zdecentralizowanym, obywatelskim i opartym na modelu terytorialnym. To niezbędny element ustroju demokratycznego - gdzie rzeczywisty i ciągły udział obywateli w życiu publicznym i sprawowaniu władzy, a nie jedynie udział w wyborach, stanowi sedno życia politycznego. Ustrój musi więc umożliwiać obywatelom udział w zarządzaniu państwem, a nie tylko udział w procesie wyborczym ${ }^{12}$. Praktyka funkcjonowania samorządu nie jest zaś wolna od problemów, swoistych „chorób władzy samorządowej”. Do najważniejszych z nich można zaliczyć fasadowość demokracji przedstawicielskiej (słabość rad, szczególnie w relacjach $\mathrm{z}$ jednoosobowym organem wykonawczym gminy), brak przejrzystości i jawności działania organów samorządu, a także dość archaiczną formułę partycypacji obywatelskiej i opór elit samorządowych przed szerszym dopuszczeniem mieszkańców do decydowania o sprawach lokalnych. O tych problemach należy rozmawiać i szukać ich rozwiązań - jednak, toutes proportions gardées, pamiętać przede wszystkim o tym, że przywrócenie samorządu unowocześniło i usprawniło państwo, pozwalając na sprawniejsze rządzenie i sprostanie nowym wyzwaniom cywilizacyjnym, a także wzmocniło pro-

10 Art. 3 ust. 1 EKSL.

${ }_{11}$ Nawiasem wspominając, wskutek nieprawidłowego tłumaczenia w polskiej wersji EKSL jest mowa o „wyborach tajnych”, a powinno być: „w głosowaniu tajnym” (ang. elected by secret ballot, franc. élus au suffrage libre).

${ }_{12}$ J. Regulski, Samorząd..., s. 4. 
cesy demokratycznej kontroli nad władzą, współodpowiedzialność obywateli za państwo i wyzwoliło mocniejsze poczucie partycypacji w sprawach publicznych.

Decentralizacja władzy publicznej przede wszystkim pozwoliła na wyzbycie się przez państwo odpowiedzialności za bieżące zarządzanie sprawami publicznymi i przekazanie tej kompetencji w ręce samorządów. Dopiero wtedy możliwe stało się dokończenie przebudowy centrum politycznego i administracyjnego państwa, z położeniem nacisku na obsługę spraw strategicznych. W rezultacie wprowadzono bardziej czytelny podział funkcji władzy publicznej między trzy główne segmenty ustroju państwowego: samorząd lokalny (w gminach i powiatach) - odpowiedzialny za zaspokajanie zbiorowych potrzeb miejscowych społeczności; samorząd regionalny (w województwach) - odpowiedzialny za politykę rozwoju regionalnego; oraz rząd i administrację rządową (centralną i terenową) - odpowiedzialne za sprawy o charakterze ogólnopaństwowym, a także za przestrzeganie prawa i nadzór nad samorządem (wojewodowie). Reforma miała bowiem nie tylko zmienić podział administracyjny kraju, ale także doprowadzić do przebudowy aparatu i bardziej efektywnego podziału kompetencji i odpowiedzialności ${ }^{13}$.

Funkcjonowanie samorządu terytorialnego można uznać za jeden z największych sukcesów polskiej transformacji. Praktyka działania administracji rządowej wskazuje jednak na instrumentalne podejście do samorządów, zaś decentralizacja oznacza nierzadko przekazywanie zadań i problemów, bez towarzyszących temu środków finansowych ${ }^{14}$. Jako efekt reform decentralizacyjnych administracja centralna utraciła

${ }^{13}$ Jednym $\mathrm{z}$ efektów zmian była zmiana roli wojewody w stosunku do marszałka województwa i samorządu wojewódzkiego. Co prawda ograniczono kompetencje wojewody, ale jednocześnie uporządkowano jego uprawnienia, więc faktycznie wzmocniono jego pozycję jako przedstawiciela rządu w terenie. Niemniej jednak pojęcie gospodarza terenu, które dotąd utożsamiane było właśnie z wojewodą, stało się domeną samorządu terytorialnego - marszałka województwa.

${ }^{14}$ Jest to widoczne np. w oświacie, gdzie środki przekazywane samorządowi w postaci subwencji oświatowej nie są wystarczające i większość gmin musi dopłacać do utrzymania szkół, czerpiąc ze środków własnych, co odbywa się kosztem innych zadań - Subwencja oświatowa, http://www.wspolnota.org.pl/rankingi/ranking-oswiatowy/ subwencja-oswiatowa/ (dostęp: 26.10.2018 r.). 
dużą część swoich kompetencji i wpływu na bieżące sprawy publiczne. Zrodziły się nowe pola napięć między rządem i samorządem terytorialnym, a w dłuższej perspektywie nie obyło się bez tendencji recentralizacyjnych. Początkowo problem dotyczył szczególnie kwestii zarządzania i dystrybucji środków UE przeznaczonych na rozwój regionalny (funduszy regionalnych) ${ }^{15}$, w których władza centralna od początku grała główną rolę. W tym celu pojawily się nowe struktury - ze specyficznym nazewnictwem oraz zadaniami - stosujące się ściśle do dokumentów UE. Na czele krajowego systemu - jako Instytucja Zarządzająca - stoi minister właściwy do spraw rozwoju regionalnego, który odpowiada za koordynację w zakresie wykorzystania środków pochodzących ze źródeł zagranicznych, w tym z budżetu Unii Europejskiej, przeznaczonych na dofinansowanie programów operacyjnych. Kolejny szczebel tworzą Instytucje Pośredniczące, czyli organy administracji publicznej lub inne jednostki sektora finansów publicznych, którym powierzono w drodze porozumienia z Instytucją Zarządzającą część zadań związanych z realizacją programu operacyjnego. Poniżej tego poziomu administracji funkcjonują Instytucje Wdrażające - podmioty publiczne lub prywatne, którym powierzono realizację zadań odnoszących się bezpośrednio do beneficjentów środków europejskich.

Widoczne od dłuższego czasu tendencje recentralizacyjne nasilają się, stopniowo odbierając samorządowi kontrolę nad kolejnymi obszarami zadań i zacieśniając nadzór nad samorządem. Dalsze działania ograniczające samorządom możliwość skutecznego działania mogą wręcz sprowadzić go do roli wykonawcy poleceń centrum, pozbawionego politycznej i zadaniowej samodzielności. Po roku 1999 nastąpiło wiele niekorzystnych dla samorządów zmian, $\mathrm{w}$ tym kwestie związane z udziałem w podatkach PIT i CIT, zacieśnianie centralnej kontroli nad zasobami w systemie opieki zdrowotnej, lekceważenie podmiotowości samorządów przy dokonywaniu zmian granic gmin, próba nadmiernego poszerzenia kompetencji organów nadzorczych nad samorządem czy nieudane podejścia do wprowadzenia zarządzania metropolital-

${ }^{15}$ M. Kulesza, Słowo końcowe, Pełnomocnik i polityka [w:] J. Milewicz, A. Wołek, Reformatorzy i politycy: gra o reformę ustrojowa 1998 roku widziana oczami jej aktorów, Warszawa 2000, s. 230. 
nego. W ostatnich latach nastąpiło wręcz centralistyczne przyspieszenie, widoczne zarówno w kształcie reformy edukacji, centralizacji funduszy ochrony środowiska i administracji ochrony środowiska, planowanej centralizacji urzędów pracy, próby radykalnego rozszerzenia kompetencji nadzorczych RIO, a także centralistycznej formuły programu „Mieszkanie+”, wchodzącej w pole do tej pory wykonywane przez samorządy w ramach budownictwa komunalnego. Jeśli kierunek zmian zostanie utrzymany, w niedługim czasie samorząd terytorialny może stać się strukturą pozbawioną realnej samodzielności i własnych kompetencji umożliwiających niezależne od władzy funkcjonowanie. Bez formalnej likwidacji samorządu może więc okazać się, że struktura władzy publicznej zmierza nieuchronnie w kierunku centrum, przejmując po kawałku kompetencje poukładane wcześniej w logiczny sposób na poszczególnych szczeblach jednostek samorządu terytorialnego.

Antidotum na tendencje centralizujące nie może być jednak jedynie obrona status quo, tym bardziej że wobec działania organów samorządu formułuje się sporo zarzutów. Jednoosobowe przywództwo wójtów, burmistrzów i prezydentów miast oparte jest często na wyidealizowanej koncepcji silnego lidera, który najlepiej rozumie i zaspokaja potrzeby mieszkańców - tymczasem takie autorytatywne podejście wydaje się coraz mniej aktualne. W obliczu coraz szerszego wkraczania do samorządu idei governance, współzarządzania oraz popularności budżetów partycypacyjnych, ruchów miejskich i różnych form konsultacji społecznych poszukuje się alternatywnych modeli przywództwa, opartych na otwartej komunikacji, współdecydowaniu i zarządzaniu wspólnotowym (communityship) ${ }^{16}$. Samorządność potrzebuje świeżego ujęcia i skupienia na nowych rozwiązaniach, zarówno w kwestiach samodzielności decyzyjnej i finansowej, jak i odbudowywania wspólnoty i demokracji lokalnej, a także nowych wyzwaniach technologicznych. Do wyzwań przyszłości - ale de facto już teraźniejszości - należy chociażby idea inteligentnego miasta (smart city), czyli obszaru składającego się z czterech głównych elementów:

${ }^{16}$ H. Mintzberg, Rebalancing Society: Radical Renewal Beyond Left, Right, and Center, http://www.mintzberg.org/sites/default/files/rebalancing_society_pamphlet.pdf (dostęp: 26.10 .2018 r.). 
1) kreatywnej populacji realizującej działania intensywnie wykorzystujące wiedzę lub klaster takich działań;

2) efektywnie działających instytucji i procedur w zakresie tworzenia wiedzy, umożliwiających jej nabywanie, adaptację i rozwój;

3) rozwiniętej infrastruktury szerokopasmowej, cyfrowych przestrzeni, e-usług oraz narzędzi on-line do zarządzania wiedzą;

4) udokumentowanej zdolności do innowacji, zarządzania i rozwiązywania problemów, które pojawiają się po raz pierwszy, ponieważ innowacyjność i zarządzanie w warunkach niepewności są kluczowe do oceny inteligencji ${ }^{17}$.

Tworzenie i rozwój „inteligentnych miast” prowadzi do uzyskiwania korzyści zarówno przez zarządzających nimi, jak i ich mieszkańców. Dzięki zaangażowaniu wspólnoty mieszkańców w działanie i ulepszanie miasta taką jednostką łatwiej się zarządza, choćby przez udoskonalenie dostępu do informacji, opracowanie procedur wspomagających efektywne działanie urzędów i służb. Współzarządzanie miastem sprawia, że jego mieszkańcom żyje się wygodniej, m.in. dlatego, że mogą szybciej załatwiać sprawy w urzędach, korzystają z lepiej działającej komunikacji zbiorowej, czują się bezpieczniej czy dlatego, że dysponują wieloma aktualnymi informacjami o tym, co ciekawego dzieje się w mieście, jak interesująco można spędzić wolny czas itp. ${ }^{18}$ Warunkiem powodzenia tego projektu jest to, aby mieszkańcy stali się aktywnymi uczestnikami tego procesu, a doza autonomii decyzyjnej i ustrojowej pozwalała na wypracowanie rozwiązań służących efektywnemu działaniu ${ }^{19}$.

Nie ma powodów, aby przypuszczać, że przejmowanie kompetencji samorządu przez centrum da lepsze efekty przy wykonywaniu zadań publicznych, ponieważ dotychczasowe doświadczenia wskazują, że władza centralna nie jest bardziej skuteczna od samorządowej (np. zdecentralizowane usługi komunalne czy edukacja w kontraście do scentralizowa-

17 N. Komninos, Intelligent Cities and Globalisationof Innovation Networks, London-New York 2008.

${ }_{18}$ M. Bogobowicz, J. Domański, Kiedy miasto jest inteligentne?, http://www. arcanagis.pl/kiedy-miasto-jest-inteligentne/ (dostęp: 26.10.2018 r.).

19 Szerzej na temat inteligentnych miast: Smart City - Informacja przestrzenna w zarzadzaniu inteligentnym miastem, red. D. Gotlib, R. Olszewski, Warszawa 2016. 
nej ochrony zdrowia). Alternatywą wobec ograniczania samorządności i rosnącej kontroli władzy centralnej może zaś być silniejsze upodmiotowienie wspólnot lokalnych, które nie tylko obserwują poczynania władzy lokalnej, ale mają realne instrumenty współdecydowania i rozliczania organów samorządowych za wszystkie niedociągnięcia czy porażki. To do mieszkańców jednostek samorządu terytorialnego powinna więc należeć najważniejsza rola ewaluacyjna względem poczynań władzy lokalnej.

Debata nad przyszłością samorządu powinna więc koncentrować się na umocnieniu samorządu $w$ relacjach $\mathrm{z}$ centrum i wprowadzeniu jakościowej zmiany wewnątrz samorządu, ze szczególnym uwzględnieniem wspólnot lokalnych jako współdecydentów i aktorów zarządzania publicznego. Trzeba zastanowić się wręcz nad zwiększeniem autonomii samorządowej, a przede wszystkim uproszczeniem podziału zadań, kompetencji i zasobów pomiędzy rządem i samorządem. Recentralizacja nie jest bowiem odpowiedzią na obecne bolączki samorządu, a raczej przepisem na pogłębienie istniejących problemów i stworzenie nowych, związanych z niedostatkami efektywności władzy centralnej.

\section{Bibliografia:}

Izdebski H., Samorzad terytorialny. Podstawy ustroju i działalności, Warszawa 2009 Izdebski H., Kulesza M., Administracja publiczna. Zagadnienia ogólne, Warszawa 2004

Komninos N., Intelligent Cities and Globalisationof Innovation Networks, London-New York 2008

Kulesza M., Ile decentralizacji w centralizacji, czyli o nawykach uczonych administratywistów, ST 2009/12

Kulesza M., Słowo końcowe, Pełnomocnik i polityka [w:] J. Milewicz, A. Wołek, Reformatorzy i politycy: gra o reforme ustrojowa 1998 roku widziana oczami jej aktorów, Warszawa 2000

Mintzberg H., Rebalancing Society: Radical Renewal Beyond Left, Right, and Center, http://www.mintzberg.org/sites/default/files/rebalancing_society_pamphlet.pdf Regulski J., Samorząd a model państwa, „Infos” z 20.05.2010 r.

Smart City - Informacja przestrzenna w zarzadzaniu inteligentnym miastem, red. D. Gotlib, R. Olszewski, Warszawa 2016 